\title{
A179 SINGLE INJECTION OF ANTIGEN-SPECIFIC REGULATORY TR1 LYMPHOCYTES PROTECTS MICE FROM SEVERE COLLAGEN-INDUCED ARTHRITIS
}

D Martire, ${ }^{1}$ A-L Bonnefont, ${ }^{1}$ H Asnagli, ${ }^{2} \mathrm{~N}$ Belmonte, ${ }^{2} \mathrm{M}$ Jourdin-Boucard, ${ }^{2} \mathrm{~S}$ Rouquier, ${ }^{2} \mathrm{~A}$ Mantello, ${ }^{2} \mathrm{~PB}$ Fall, ${ }^{2} \mathrm{~A}$ Foussat, ${ }^{2} \mathrm{C}$ Jorgensen, ${ }^{1} \mathrm{P}$ Louis-Plence ${ }^{1}{ }^{1}$ INSERM U844, Université Montpellier, Montpellier, France; ${ }^{2}$ CNRS, Montpellier, France

\subsection{6/ard.2010.129668p}

Introduction $\operatorname{Tr} 1$ cells have been characterised as induced $\mathrm{T}$ regulatory lymphocytes (Treg) inhibiting inflammation in various chronic inflammatory models. Based on these data, a clinical trial is ongoing in Crohn's disease. However, the therapeutic potential of these cells has not yet been evaluated in rheumatoid arthritis.

Methods Collagen type II specific Tr1 clones were obtained from $T$ cell receptor transgenic mice and expanded in vitro. Selected clones showed in vitro antigen specificity, Tr1 cytokine profile (interleukin(IL)10 high/IL4 negative) and IL10- and transforming growth factor (TGF) $\beta$-dependent suppressive activity. Male DBA-1 mice were immunised with bovine type II collagen (bCII) and $3 \times 10^{6} \mathrm{Tr} 1$ cells were injected intravenously 21 or 28 days after immunisation. Hind paw swelling and clinical signs of arthritis were scored, as well as biological parameters such as the level of anti-bCII antibodies in the sera of treated mice and the cytokine profile of bCII-specific T cells.

Results A single injection of Tr1 cells at day 28 as semicurative treatment significantly inhibits the development of arthritic disease shown by reduction of disease severity and incidence. The analysis of the bCII specific $\mathrm{T}$ cell responses following euthanasia of the mice revealed an increase in interferon (IFN) $\gamma$ secretion associated with a decrease in the IL17 inflammtory cytokine.

Conclusions These preliminary data indicate that a single injection of $\operatorname{Tr} 1$ cells at disease onset could reduce disease severity and incidence in experimental arthritis. These results underscore the therapeutic potential of Tr1 cells in arthritis and confirm the clinical potential of these induced Treg. 